\title{
Specific Neisseria gonorrhoeae DNA-Probes Derived from Ribosomal RNA
}

\author{
By RUDI ROSSAU, ${ }^{1 *}$ EUGEEN VANMECHELEN, ${ }^{1}$ JOZEF DE LEY ${ }^{2}$ AND \\ HUGO VAN HEUVERSWIJN ${ }^{1}$ \\ ${ }^{1}$ Innogenetics NV, Industriepark 7, bus 4, B-9710 Zwijnaarde, Belgium \\ ${ }^{2}$ Laboratorium voor Microbiologie en microbiële Genetica, Rijksuniversiteit, \\ K. L. Ledeganckstraat 35, B-9000 Gent, Belgium
}

(Received 11 November 1988; revised 16 January 1989; accepted 26 January 1989)

\begin{abstract}
Eighteen sequences complementary to less-conserved regions within the $16 \mathrm{~S}$ and $23 \mathrm{~S}$ ribosomal ribonucleic acid ( $\mathrm{RNA}$ ) of Neisseria gonorrhoeae were subcloned or chemically synthesized and used as probes in a dot-spot deoxyribonucleic acid (DNA): DNA hybridization format. Some of these probes exclusively detected Neisseria gonorrhoeae nucleic acid, whereas others also showed hybridization signals with nucleic acid from other bacterial species. Our results indicate that rRNA-derived DNA-probes can be used to differentiate between very closely related taxa without the use of Southern-blot analysis.
\end{abstract}

\section{INTRODUCTION}

The literature dealing with nucleic acid hybridization probes for detection and identification of micro-organisms is accumulating very rapidly (Tenover, 1988). Most of these probes, which can be either total genomic deoxyribonucleic acid (DNA), indigenous plasmids, cloned DNA fragments or synthetic oligonucleotides, target the DNA of the organism to be detected. Because of the high abundance of ribosomes in a cell, it is obvious that probes targeting the ribosomal ribonucleic acid (rRNA), can considerably increase the sensitivity of a diagnostic test. Another advantage of rRNA-derived probes lies in the single-strandedness and ubiquity of the rRNA. On the other hand, the high sequence conservation observed among rRNA cistrons of different species is considered to be an important drawback of the method. Up to now, rRNA-derived probes have been used mainly to detect large groups of organisms such as Legionella (Wilkinson et al., 1986; Edelstein, 1986), the Pseudomonas fluorescens group (Festl et al., 1986), or to differentiate between relatively distantly related species such as Mycoplasma (Göbel et al., 1987) and Chlamydia species (Palmer et al., 1986). One report describes the differentiation between the species Proteus vulgaris and Proteus mirabilis (Haun \& Göbel, 1987). These species have a DNA homology value of about $50 \%$; currently, this is the highest degree of discrimination which can be achieved using rRNA-derived probes without the use of Southern hybridizations.

In the present study, the feasibility of using rRNA-derived DNA-probes to differentiate between highly related taxa was investigated. Neisseria gonorrhoeae, Neisseria meningitidis and related taxa were chosen as test organisms because the genotypic relationships of these taxa are amply documented (e.g. Guibourdenche et al., 1986; R. Rossau and others, unpublished results), and some of the species are of high clinical relevance. In spite of the high sequence conservation of rRNA cistrons, our results prove that differentiation at the species level and even at the subspecies level can be achieved with rRNA-derived DNA-probes without the use of Southernblot analysis.

Abbretiations: HT, hybridization temperature; WT, wash temperature; FA, formamide; PB, phosphate buffer. 
Table 1. Strains used

\begin{tabular}{|c|c|c|c|c|c|}
\hline $\begin{array}{c}\text { Strain } \\
\text { no. }\end{array}$ & Name & $\begin{array}{c}\text { Culture } \\
\text { collection } \\
\text { no.* }\end{array}$ & $\begin{array}{c}\text { Strain } \\
\text { no. }\end{array}$ & Name & $\begin{array}{c}\text { Culture } \\
\text { collection } \\
\text { no. }{ }^{*}\end{array}$ \\
\hline 1 & Neisseria gonorrhoeae & NCTC $8375^{\mathrm{T}}$ & 32 & Neisseria subflava & ITG 3821 \\
\hline 2 & Neisseria gonorrhoeae & ITG 4339 & 33 & Neisseria sicca & ITG 3383 \\
\hline 3 & Neisseria gonorrhoeae & ITG 4085 & 34 & Neisseria elongata subsp. & \\
\hline 4 & Neisseria gonorrhoeae & ITG 4308 & & elongata & NCTC $10660^{\mathrm{T}}$ \\
\hline 5 & Neisseria gonorrhoeae & ITG 3939 & 35 & Neisseria elongata subsp. & \\
\hline 6 & Neisseria gonorrhoeae & ITG 4363 & & glycolytica & NCTC 11050 \\
\hline 7 & Neisseria gonorrhoeae & ITG 4367 & 36 & Neisseria canis & $\operatorname{ATCC} 14687^{\mathrm{T}}$ \\
\hline 8 & Neisseria gonorrhoeae & ITG 4401 & 37 & Neisseria animalis & NCTC $10212^{\mathrm{T}}$ \\
\hline 9 & Neisseria gonorrhoeae & ITG 4437 & 38 & Neisseria denitrificans & $\operatorname{ATCC} 14686^{\mathrm{T}}$ \\
\hline 10 & Neisseria meningitidis & NCTC $10025^{\mathrm{T}}$ & 39 & CDC group $M-5$ & CCUG 4007 \\
\hline 11 & Neisseria meningitidis & ITG 3342 & 40 & CDC group EF-4a & CDC T-191/78 \\
\hline 12 & Neisseria meningitidis & ITG 3343 & 41 & Kingella denitrificans & NCTC $10995^{\mathrm{T}}$ \\
\hline 13 & Neisseria meningitidis & ITG 3345 & 42 & Kingella denitrificans & NCTC 10997 \\
\hline 14 & Neisseria meningitidis & ITG 3346 & 43 & Kingella kingae & NCTC 10746 \\
\hline 15 & Neisseria meningitidis & ITG 3348 & 44 & Simonsiella muelleri & ATCC 29452 \\
\hline 16 & Neisseria meningitidis & ITG 3349 & 45 & Simonsiella crassa & ATCC $15533^{\mathrm{T}}$ \\
\hline 17 & Neisseria meningitidis & ITG 3350 & 46 & Simonsiella steedae & ATCC 27398 \\
\hline 18 & Neisseria meningitidis & ITG 3357 & 47 & Simonsiella species & ATCC 27381 \\
\hline 19 & Neisseria meningitidis & ITG 3362 & 48 & Alysiella filiformis & CCUG $3710^{\mathrm{T}}$ \\
\hline 20 & Neisseria polysaccharea & CIP N462 & 49 & Eikenella corrodens & NCTC $10596^{\mathrm{T}}$ \\
\hline 21 & Neisseria lactamica & NCTC 10616 & 50 & Eikenella corrodens & HIM 801-1 \\
\hline 22 & Neisseria lactamica & NCTC $10617^{\mathrm{T}}$ & 51 & Chromobacterium violaceum & NCTC $9757^{\mathrm{T}}$ \\
\hline 23 & Neisseria lactamica & ITG 3689 & 52 & Chromobacterium fluviatile & LMG 6574 \\
\hline 24 & Neisseria lactamica & ITG 3690 & 53 & Aquaspirillum dispar & ATCC 27650 \\
\hline 25 & Neisseria cinerea & NCTC 10294 & 54 & Pseudomonas testosteroni & ATCC 17407 \\
\hline 26 & Neisseria mucosa & CIP 59.51 & 55 & Oligella urethralis & LMG 6227 \\
\hline 27 & Neisseria mucosa & CIP 59.48 & 56 & Haemophilus ducreyi & $\operatorname{CIP} 542^{\mathrm{T}}$ \\
\hline 28 & Neisseria mucosa & CIP 59.47 & 57 & Kingella indologenes & NCTC $10717^{\mathrm{T}}$ \\
\hline 29 & Neisseria macacae & CIP N4176 & 58 & Moraxella (Branhamella) & \\
\hline 30 & Neisseria flavescens & ATCC $13120^{\mathrm{T}}$ & & catarrhalis & NCTC 4103 \\
\hline 31 & Neisseria subflava & ATCC 10555 & 59 & Escherichia coli & B \\
\hline
\end{tabular}

*ATCC, American Type Culture Collection, Rockville, Md., USA; CCUG, Culture Collection of the University of Göteborg, Department of Clinical Bacteriology, University of Göteborg, Sweden; CDC, Centers for Disease Control, Atlanta, Ga., USA; CIP, Collection de l'Institut Pasteur, Paris, France; HIM, Hygiene-Institut, Marburg, FRG; ITG, Instituut voor Tropische Geneeskunde, Antwerp, Belgium; LMG, Laboratorium voor Microbiologie, Rijksuniversiteit, Gent, Belgium; NCTC, National Collection of Type Cultures, Central Public Health Laboratory, London, UK: T, type strain.

\section{METHODS}

Strains used. The strains used are listed in Table 1. The identity of the strains was checked by conventional methods.

DNA preparations. High-molecular-mass genomic DNA was prepared essentially by the method described by Marmur (1961). Plasmid DNA was isolated by the method described by Kahn et al. (1979) and purified by CsClgradient centrifugation.

Fixation of denatured DNA on nitrocellulose membranes. The DNA solution (approximately $25 \mathrm{ng} \mathrm{DNA} \mu l^{-1}$ in $10 \mathrm{~mm}$-Tris/ $\mathrm{HCl}$, pH 7.6, $1 \mathrm{~mm}$-EDTA) was heated for $10 \mathrm{~min}$ at $95^{\circ} \mathrm{C}$, put on ice, and adjusted to $6 \times \mathrm{SSC}$ $(1 \times \mathrm{SSC}$ is $0.15 \mathrm{M}-\mathrm{NaCl}, 0.015 \mathrm{M}$-sodium citrate, $\mathrm{pH} 7.0)$. The appropriate amount of solution was applied to a BA85 membrane (Schleicher and Schuell) in a dot-spot manifold (Bio-Rad). After air-drying, the membrane was baked at $80^{\circ} \mathrm{C}$ for $2 \mathrm{~h}$.

Construction of the probes 3 and 6 . The plasmids pNGDI and pNGK 3 contain probes 3 and 6 , respectively, as inserts. They were constructed from pNG4 and pNG3 respectively, which are recombinant plasmids containing part of the 16S rRNA gene of $N$. gonorrhoeae NCTC $8375^{\mathrm{T}}$ cloned in pTZ18R (Pharmacia) (R. Rossau,

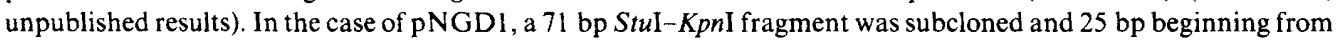
the $S t u I$ site were subsequently removed by Exonuclease III (Stratagene) and mung bean nuclease (Stratagene) treatment. For the construction of pNGK3, 63 bp were similarly removed from the $3^{\prime}$ end of the insert of pNG3. 
The resulting plasmid was cleaved with restriction enzymes $S p h \mathrm{I}$ and BstXI, followed by blunting of the sticky ends using Klenow enzyme and intramolecular ligation. The restriction enzymes were purchased from Boehringer Mannheim or BioLabs and used as recommended by the suppliers.

Oligonucleotide synthesis and purification. The oligonucleotides were synthesized by the phosphite-triester method on a Gene Assembler 18-5800-01 (Pharmacia) or a Cyclone 8400 (New Brunswick). The deprotected oligonucleotides were purified on a $15 \%(\mathrm{w} / \mathrm{v})$ polyacrylamide gel in $7 \mathrm{M}$-urea. The gel slice containing the oligonucleotide was chopped in pieces and the oligonucleotide was eluted overnight and desalted on a Sephadex G-25 (Pharmacia) column as described by Maniatis et al. (1982).

Probe labelling. The synthetic oligonucleotides used as probes were labelled using T4-polynucleotide kinase (Pharmacia) and $\left[\gamma^{32}\right.$ P]ATP (Amersham) (Maniatis et al., 1982). To eliminate interference due to vector sequences during hybridization, the inserts of pNGDl (probe 3) and pNGK3 (probe 6) were cut-out using restriction enzymes and purified by agarose gel electrophoresis. The purified inserts were labelled by filling in the sticky-ends with $\left[\alpha^{-32}\right.$ P]dATP (Amersham) using Klenow enzyme (Boehringer Mannheim) (Maniatis et al., 1982). Unincorporated label was removed using a Bio-Gel P-6DG (Bio-Rad) spun-column (Maniatis et al., 1982).

Hybridizations. A similar hybridization protocol was followed in all experiments except that conditions were adapted to the nature of the probes used. Prehybridization was usually done in plastic bags in $3 \times \mathrm{SSC}, 25 \mathrm{~mm}-$ sodium phosphate buffer, pH $7 \cdot 1$ (PB), deionized formamide (FA) $(20 \%, v / v)$, Ficoll $(0.02 \%, w / v)$, bovine serum albumin $(0.02 \%, w / v)$, polyvinylpyrrolidone $(0.02 \%, \mathrm{w} / \mathrm{v})$ and sheared, denatured salmon sperm DNA $\left(0.1 \mathrm{mg} \mathrm{m}^{-1}\right)$ at the temperature of hybridization for periods from $30 \mathrm{~min}$ to $4 \mathrm{~h}$. Hybridization was allowed to proceed for periods from $1 \mathrm{~h}$ to overnight in the same solution to which approximately 0.5 to $1 \times 10^{6} \mathrm{c} \cdot \mathrm{p} \cdot \mathrm{m}$. $\mathrm{ml}^{-1}$ ${ }^{32} \mathrm{P}$-labelled probe was added. The hybridization temperature (HT) depended on the experimental requirements. Following a brief rinse in $3 \times \mathrm{SSC}, 25 \mathrm{~mm}-\mathrm{PB}, 20 \%(\mathrm{v} / \mathrm{v}) \mathrm{FA}$ at room temperature, the membranes were washed for 15 to $30 \mathrm{~min}$ in $3 \times \mathrm{SSC}, 25 \mathrm{~mm}-\mathrm{PB}, 20 \%(\mathrm{v} / \mathrm{v}) \mathrm{FA}$ at the wash temperature (WT) indicated in the figures. Afterwards, the membranes were rinsed in $1.5 \times \mathrm{SSC}$ at room temperature for approximately $10 \mathrm{~min}$, dried and autoradiographed.

Table 2. Probes used, their allocation on the rRNA molecule, length, percentage sequence homology with the corresponding sequences in the rRNA molecules of P. testosteroni and E. coli, and hybridization results with DNA from the type strains of $N$. gonorrhoeae and N. meningitidis

Abbreviations: EC, E. coli; PT, P. testosteroni $; \mathrm{NG}^{\mathrm{T}}, N$. gonorrhoeae (type strain); $\mathrm{NM}^{\mathrm{T}}, N$. meningitidis (type strain).

\begin{tabular}{|c|c|c|c|c|c|c|c|}
\hline \multirow[b]{2}{*}{ Probe } & \multirow[b]{2}{*}{ rRNA } & \multirow[b]{2}{*}{$\begin{array}{l}\text { Region } \\
\text { (in Fig. 1) }\end{array}$} & \multirow[b]{2}{*}{$\begin{array}{l}\text { Length } \\
\text { (bases) }\end{array}$} & \multicolumn{2}{|c|}{$\begin{array}{c}\text { Percentage } \\
\text { homology }\end{array}$} & \multicolumn{2}{|c|}{$\begin{array}{l}\text { Hybridization } \\
\text { with DNA } \\
\text { from:* }\end{array}$} \\
\hline & & & & PT & EC & $\mathrm{NG}^{\mathrm{T}}$ & $\mathrm{NM}^{\mathrm{T}}$ \\
\hline 1 & $16 S$ & III & 27 & 67 & 37 & + & - \\
\hline 2 & $16 S$ & III & 37 & 64 & 46 & + & - \\
\hline 3 & $16 \mathrm{~S}$ & III & 47 & 72 & 55 & + & - \\
\hline 4 & $16 \mathrm{~S}$ & III & 57 & 72 & 56 & + & - \\
\hline 5 & $16 \mathrm{~S}$ & V & 34 & 53 & 44 & + & - \\
\hline 6 & $16 \mathrm{~S}$ & VII & 56 & 75 & 70 & + & + \\
\hline 7 & $23 \mathrm{~S}$ & VII & 27 & - & 54 & + & + \\
\hline 8 & $23 \mathrm{~S}$ & VII & 28 & - & 57 & + & + \\
\hline 9 & $16 \mathrm{~S}$ & I & 32 & 38 & 63 & + & - \\
\hline 10 & $23 \mathrm{~S}$ & VI & 39 & - & 40 & + & + \\
\hline 11 & $23 \mathrm{~S}$ & I & 33 & - & 48 & + & - \\
\hline 12 & $16 S$ & IV & 28 & 54 & 46 & + & + \\
\hline 13 & $16 S$ & II & 24 & 58 & 42 & + & - \\
\hline 14 & $16 S$ & VI & 26 & 50 & 46 & + & - \\
\hline 15 & $23 \mathrm{~S}$ & II & 21 & - & 52 & + & + \\
\hline 16 & $23 \mathrm{~S}$ & III & 28 & - & 43 & + & - \\
\hline 17 & $23 \mathrm{~S}$ & $\mathrm{~V}$ & 30 & - & 60 & + & - \\
\hline 18 & $23 \mathrm{~S}$ & IV & 28 & - & 46 & + & + \\
\hline
\end{tabular}

* Under stringent conditions, i.e. wash temperature approximately $5{ }^{\circ} \mathrm{C}$ below the dissociation temperature versus $\mathrm{NG}^{\mathrm{T}}$ DNA. 


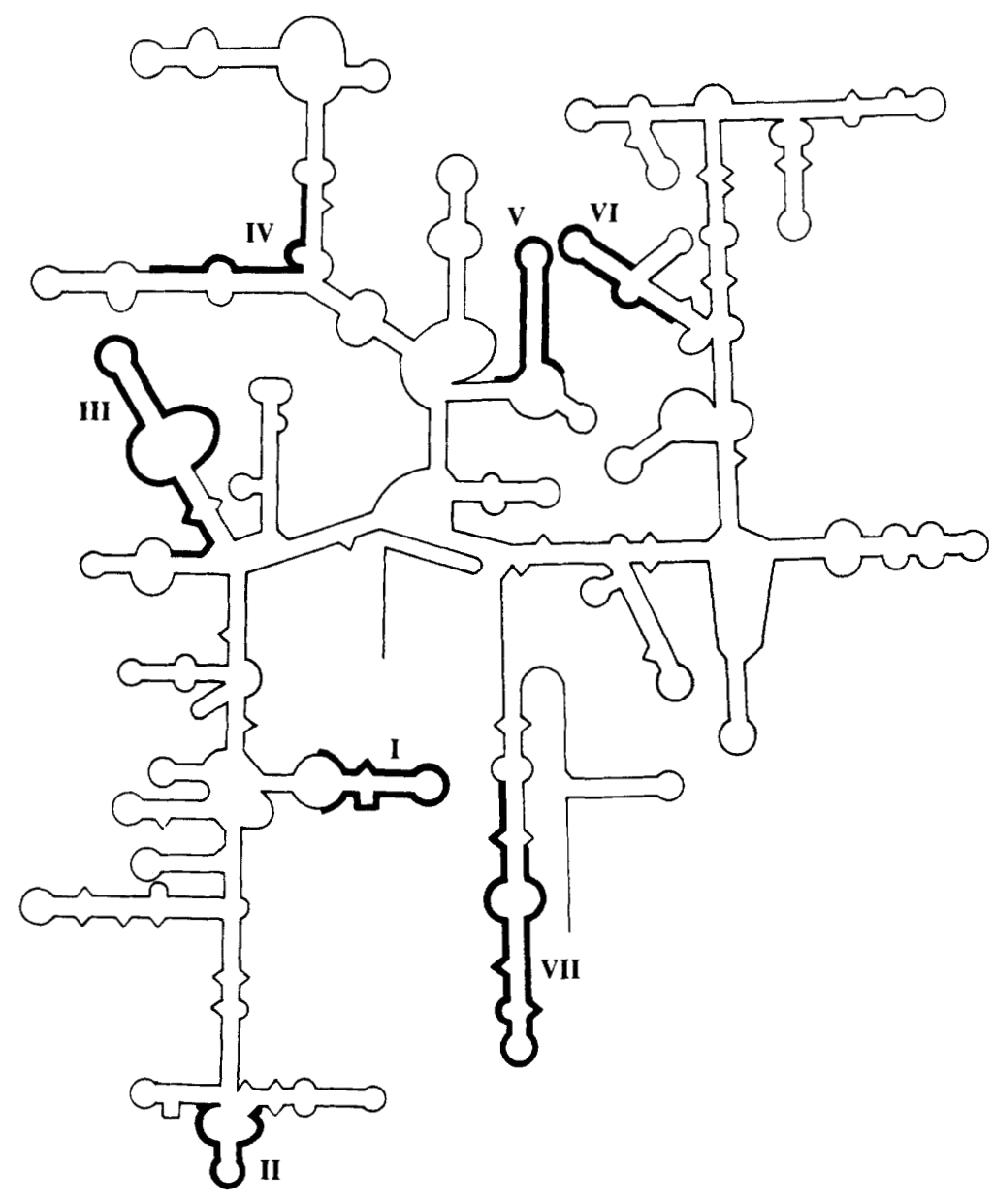

Fig. 1. Allocation of the regions from which DNA-probes were constructed on the presumptive 16S rRNA secondary structure of $N$. gonorrhoeae (R. Rossau and others, unpublished results). These regions are indicated by thick lines and are identified by a Roman numeral.

\section{RESULTS AND DISCUSSION}

\section{Probes used}

In order to select $N$. gonorrhoeae-specific probes, one of the rRNA cistrons of the type strain of $N$. gonorrhoeae was cloned and sequenced (Rossau et al., 1988; unpublished results). Evolutionarily less-conserved regions within the cistron were identified by alignment with known sequences (Dams et al., 1988). Some of these regions were subcloned (probes 3 and 6) or chemically synthesized (probes 1,2, 4, 5 and 7 to 18) and used as hybridization probes (Table 2). The locations of the probes derived from the $16 \mathrm{~S}$ rRNA gene which were used in this study are shown on the diagram in Fig. 1. Fig. 2 shows the allocation of the 23S rRNA-derived probes on the secondary structure of the 23S rRNA molecule of Escherichia coli. From region III (in Fig. 1) of the $16 \mathrm{~S}$ rRNA, four probes with different lengths $(27,37,47$ and 57 bases for probes $1,2,3$ and 4, respectively) were tested. Probes 7 and 8 were derived from the same region of the $23 \mathrm{~S}$ rRNA (region VII, Fig. 2). The sequence of probe 8 is identical to the sequence of probe 7 , 


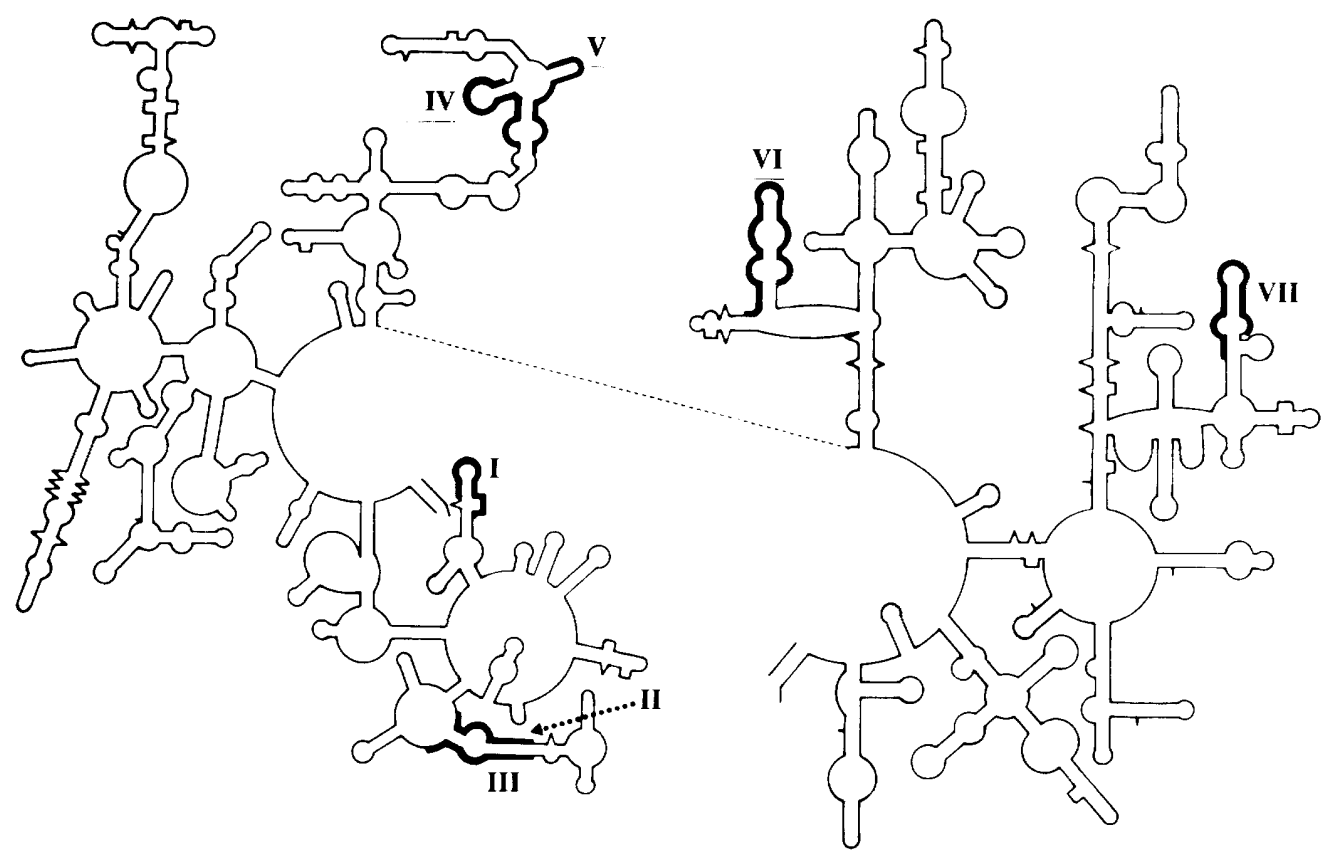

Fig. 2. Allocation of the regions from which DNA-probes were constructed on the 23S rRNA secondary structure of $E$. coli (Noller, 1984). The regions are indicated by thick lines and are identified by a Roman numeral.

except that in probe 8 the adenosine residue at position 13 was deleted. Only one probe was used from all other regions.

\section{Specificity of the probes}

The criterion for specificity was the ability to differentiate between the $N$. gonorrhoeae and $N$. meningitidis type strains. Several independent studies (Kingsbury, 1967; Elwell \& Falkow, 1977; Hoke \& Vedros, 1982; Riou et al., 1983; Guibourdenche et al., 1986; R. Rossau and others, unpublished results) have shown that, despite their distinct pathogenic character, both species are genotypically extremely highly related. The DNA :DNA hybridization homology values reported between representatives of both species range between 64 and $93 \%$. Using the initial renaturation rate method (De Ley et al., 1970), the degree of binding between the type strains of both species was $74 \%$ (mean of three measurements; R. Rossau and others, unpublished results). These values are most of ten found among members of the same species. Species and subspecies are extremely ambiguous concepts. Recently, a proposal was put forward stating that 'a species generally would include strains with approximately $70 \%$ or greater DNA-DNA relatedness and with $5^{\circ} \mathrm{C}$ or less delta $T \mathrm{~m}$ ' (Wayne et al., 1987).

In a preliminary series of experiments, the probes were hybridized with dot-spotted, denatured, genomic DNA of $N$. gonorrhoeae NCTC $8375^{\mathrm{T}}, N$. meningitidis $\mathrm{NCTC} 10025^{\mathrm{T}}$ and $E$. coli B. From the autoradiographs in Fig. 3, it is clear that all probes derived from regions I, II, III, V, and VI (Fig. 1) of the 16S rRNA and probes derived from regions I, III, and V of the 23S rRNA, are specific for the type strain of $N$. gonorrhoeae at the appropriate wash temperature (see also Table 2). This is not the case for probes derived from regions IV and VII of 16S rRNA, or for probes derived from regions II, IV, VI and VII of 23S rRNA.

Probes 1,5 and 9 were hybridized with genomic DNA from nine $N$. gonorrhoeae strains (strains 1 to 9 in Table 1) and ten N. meningitidis strains (strains 10 to 19 in Table 1). As shown in 


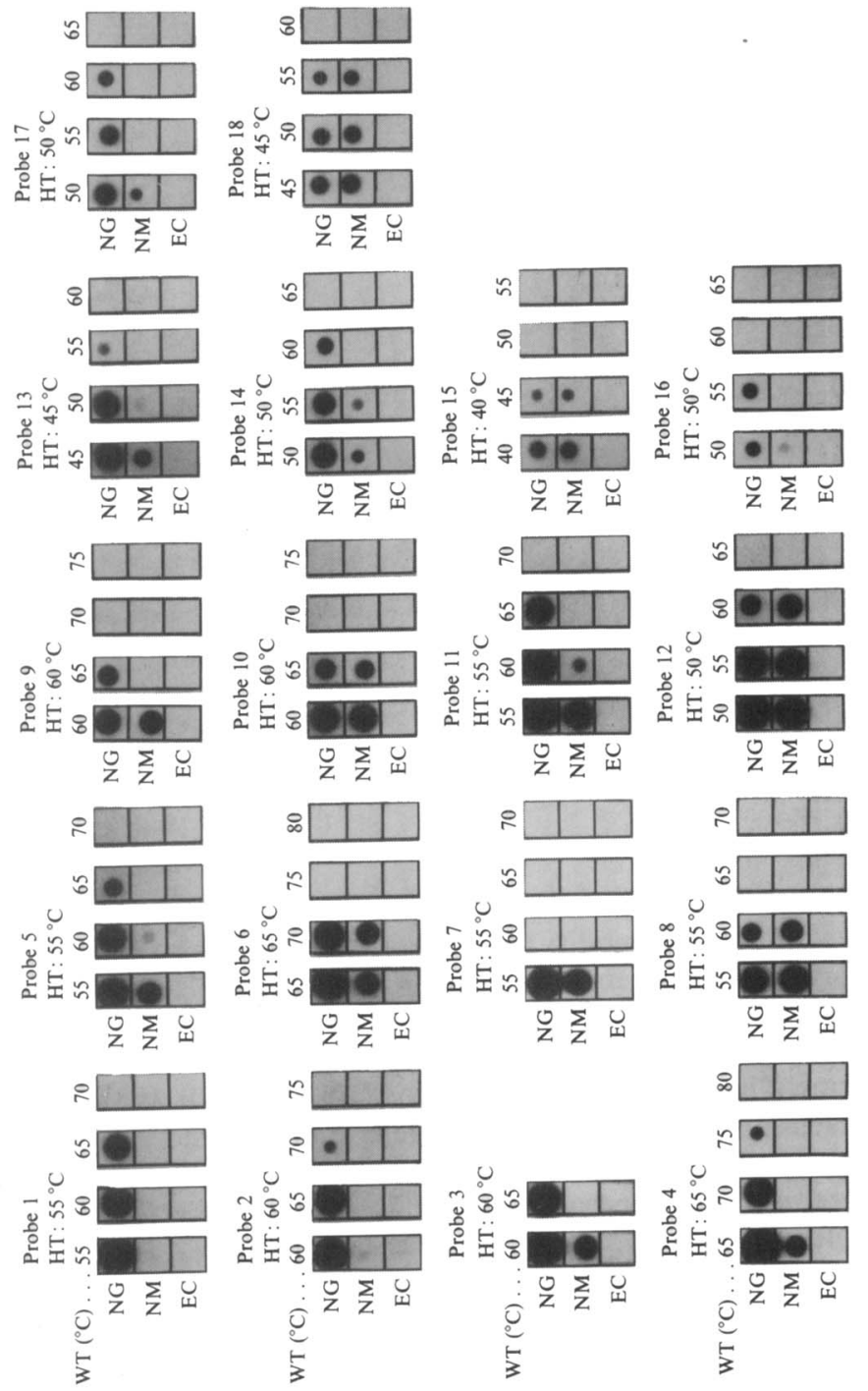

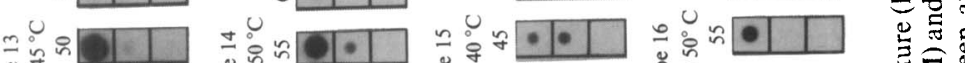

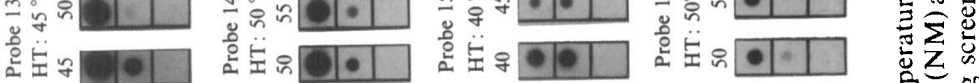

絽口回 10

解口

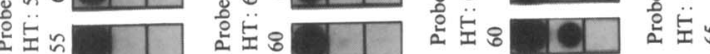

$$
\begin{aligned}
& \begin{array}{l}
\vdots \\
\vdots \\
0 \\
0 \\
3
\end{array}
\end{aligned}
$$

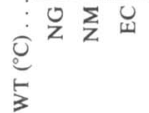

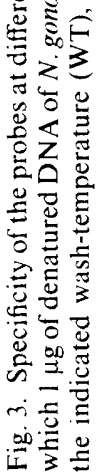



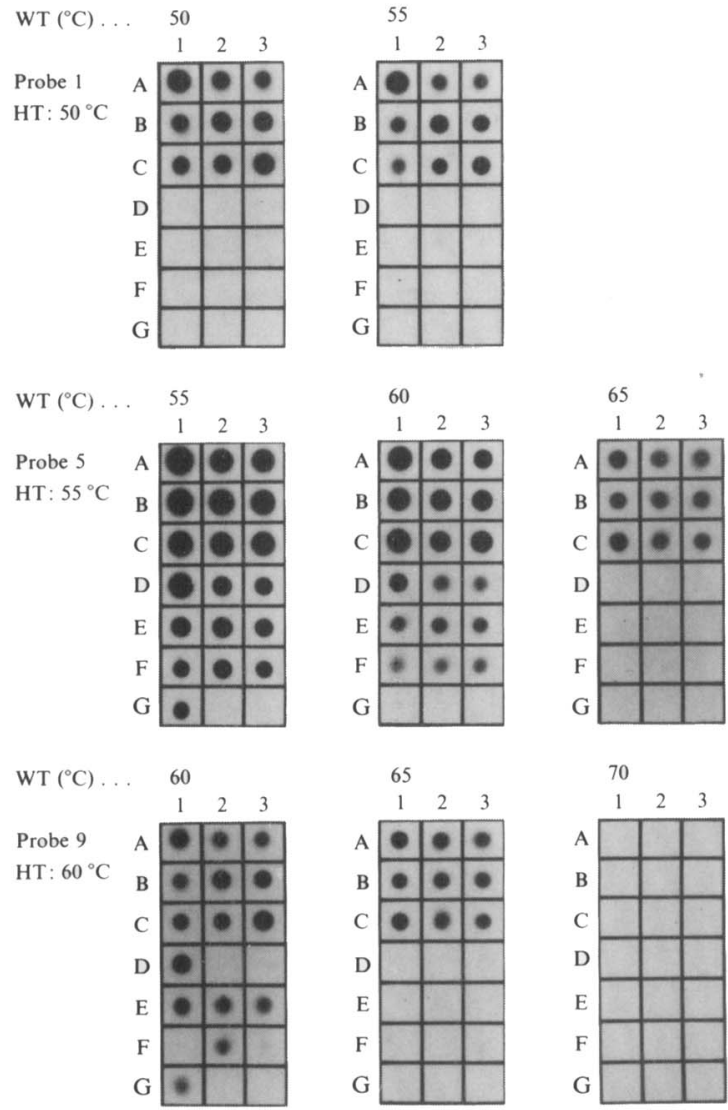

Fig. 4. Differentiation between $N$. gonorrhoeae and $N$. meningitidis strains using a dot-spot DNA : DNA hybridization procedure. Denatured DNA $(1 \mu \mathrm{g})$ from nine $N$. gonorrhoeae strains (rows A, B and C, 1 to 3), ten $N$. meningitidis strains (rows D, E and F, 1 to 3, and $\mathrm{Gl}$ ), and one strain each of $P$. testosteroni (G2) and $E$. coli $(G 3)$ were spotted onto nitrocellulose, hybridized with probe 1 (panel A), probe 5 (panel $B$ ) and probe 9 (panel C) at 50,55 and $60^{\circ} \mathrm{C}$ respectively, and washed at the temperatures indicated.

Fig. 4, these probes duplexed with the DNA from all $N$. gonorrhoeae strains tested. Probes 5 and 9 were specific for $N$. gonorrhoeae strains at high stringencies only, whereas probe 1 remained specific at low-stringency conditions.

The possibility of non-specific cross-hybridization of some of the probes was investigated by hybridizations with purified genomic DNA from a variety of bacteria, the genotypical relationships of which are shown in Fig. 5. Probes 3, 5 and 7 were hybridized with genomic DNA from seven Neisseria species and some other Gram-negative bacteria (Fig. 6). Under the conditions used, probes 3 and 5 did not form stable duplexes with any of the DNAs tested, except for $N$. gonorrhoeae DNA. Even the less-specific probe 6 did not produce a detectable signal with non-neisserial DNA. The highly specific probe 1 and the less-specific probe 10 were hybridized with purified DNA from 44 strains belonging to bacterial taxa which are highly or moderately related to $N$. gonorrhoeae in terms of rRNA cistron similarities (strains $1,7,10,17$, and 20 to 50 in Table 1) or taxa which are more distantly related (strains 51 to 59 in Table 1; see also Fig. 5). As shown in Fig. 7, probe 1 hybridizes exclusively with DNA from the $N$. gonorrhoeae strains. In contrast, probe 10 hybridizes with DNA from almost all Neisseria species 


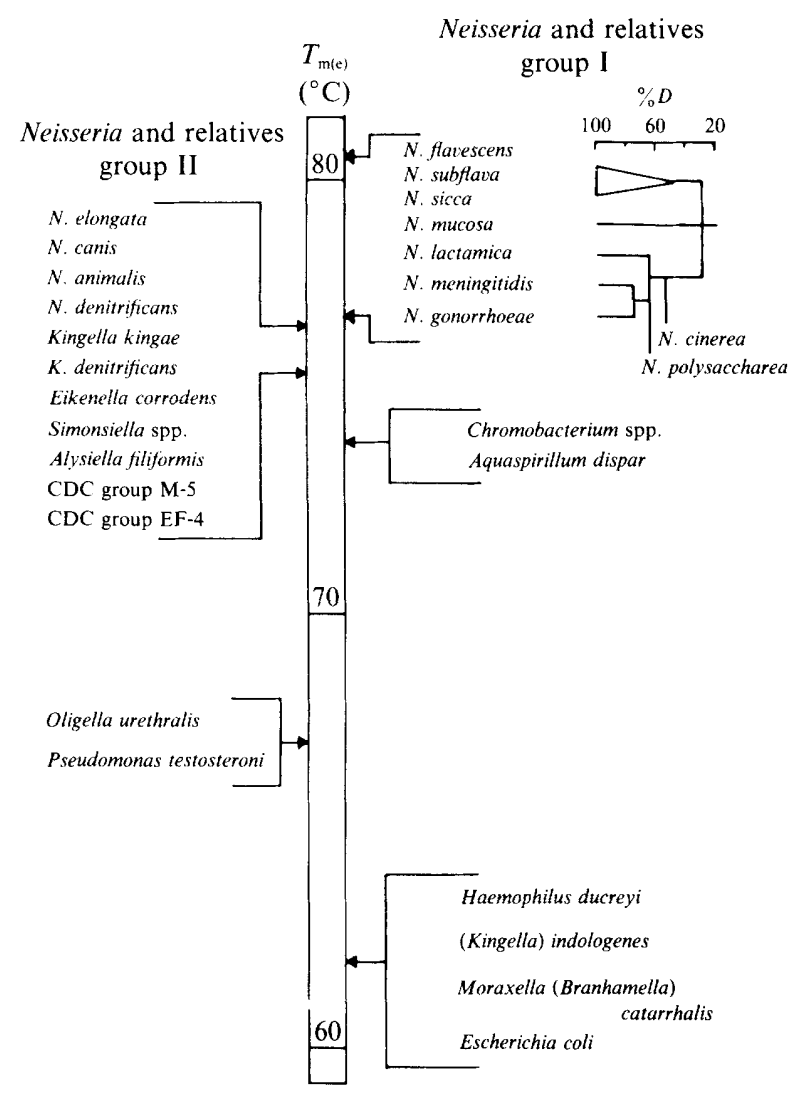

Fig. 5. Diagram representing the genotypical relationships of the organisms used. On the axis the genotypical relationships of the organisms are expressed in terms of rRNA similarities $\left(T_{\mathrm{m}(\mathrm{e})}\right.$ in $\left.{ }^{\circ} \mathrm{C}\right)$ versus reference rRNA of $N$. flavescens ATCC $13120^{\mathrm{T}}$ (R. Rossau and others, unpublished results). The $T_{\mathrm{m}(\mathrm{e})}$ is the temperature at which $50 \%$ of a DNA : rRNA hybrid is denatured (De Ley \& De Smedt, 1975). The higher the $T_{\mathrm{m}(\mathrm{e})}$, the closer the organism is related to the reference organism (in this case $N$. flavescens). The dendrogram shows the genotypical relationships of the organisms found in the uppermost part of the $T_{\mathrm{m}(\mathrm{e})}$-axis (Neisseria and relatives, group I) as deduced from DNA:DNA hybridization data and expressed in degree of binding $(\% D$; De Ley et al., 1970). All other organisms do not exhibit a significant $\% D$ with the taxa belonging to the Neisseria and relatives group I (R. Rossau and others, unpublished results). The phylogenetic relationships of $N$. cinerea and $N$. polysaccharea were deduced from DNA : DNA hybridization data published by Guibourdenche et al. (1986); the position of these organisms is indicated relative to $N$. gonorrhoeae on the DNA : DNA dendrogram. The exact taxonomical position of $N$. macacae is not known.

and DNA from Kingella kingae, Simonsiella muelleri, Simonsiella crassa and Alysiella filiformis. No hybridization signal was observed with all other DNAs, including DNA from Neisseria canis, Neisseria denitrificans and Neisseria animalis.

From the results shown in Figs 3 and 4, it is obvious that the specificity of the probes is highly dependent on the hybridization and wash conditions used. For instance, by simply altering the wash temperature, the detection range of the probes can be extended, so that one and the same probe can be used to detect $N$. gonorrhoeae specifically, or a larger group of organisms, as illustrated for probe 3 in Fig. 8.

Some properties of the probes and the results obtained are summarized in Table 2. Eleven of the probes tested hybridized with DNA from the $N$. gonorrhoeae type strain but not with DNA from the $N$. meningitidis type strain. At least three of these probes could discriminate between 

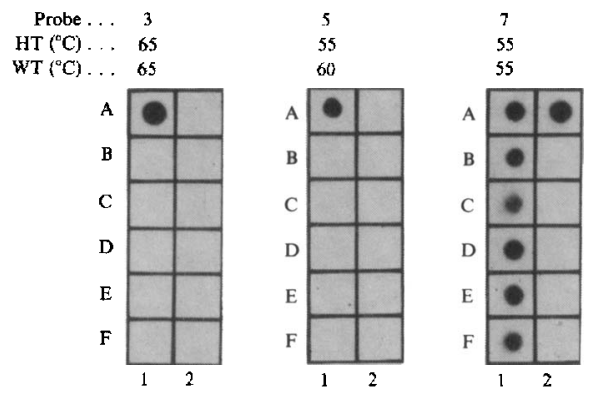

Fig. 6. Hybridization results of selected rRNA-derived DNA-probes with DNA from several representative Gram-negative bacteria. Denatured DNA $(1 \mu \mathrm{g})$ from $N$. gonorrhoeae NCTC $8375^{\mathrm{T}}$ (A1), N. meningitidis NCTC $10025^{\mathrm{T}}$ (B1), N. lactamica NCTC $10617^{\mathrm{T}}$ (Cl), N. mucosa CIP 59.51 ${ }^{\mathrm{T}}$ (D1), $N$. subflava ATCC $10555(\mathrm{E} 1), N$. flavescens ATCC $13120^{\mathrm{T}}(\mathrm{F} 1), \quad N$. elongata ssp. elongata NCTC $10660^{\mathrm{T}}$ (A2), Chromobacterium vialaceum NCTC $9757^{\mathrm{NT}}$ (B2), P. testosteroni ATCC 17407 (C2), Haemophilus ducreyi CIP 542 (D2), Moraxella (Branhamella) catarrhalis NCTC 4103 (E2) and E. coli B (F2), was spotted on nitrocellulose, hybridized at temperature HT with the probe indicated and washed at the temperature WT.

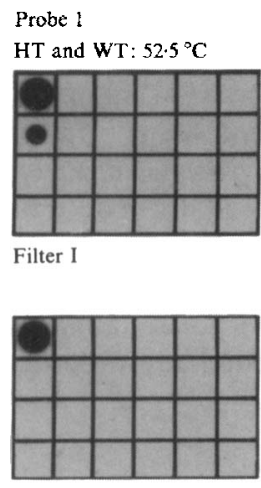

Filter Il
Probe 10

HT and WT: $55^{\circ} \mathrm{C}$

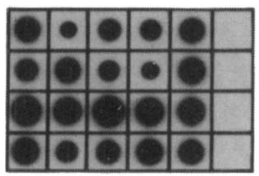

Filter I

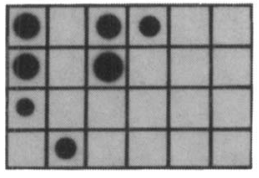

Filter II

\begin{tabular}{|c|c|c|c|c|c|}
\hline 1 & 20 & 24 & 28 & 32 & 36 \\
\hline 7 & 21 & 25 & 29 & 33 & 37 \\
\hline 10 & 22 & 26 & 30 & 34 & 38 \\
\hline 17 & 23 & 27 & 31 & 35 & 51 \\
\hline
\end{tabular}

Filter I

\begin{tabular}{|l|l|l|l|l|l|}
\hline 1 & 40 & 44 & 48 & 52 & 56 \\
\hline 10 & 41 & 45 & 49 & 53 & 57 \\
\hline 20 & 42 & 46 & 50 & 54 & 58 \\
\hline 39 & 43 & 47 & 51 & 55 & 59 \\
\hline
\end{tabular}

Filter II

Fig. 7. Hybridization of probe 1 and probe 10 with DNA from a variety of Gram-negative bacteria. From each strain (the numbers correspond to the numbering in Table 1) denatured DNA ( $\mu \mathrm{g})$ was applied to nitrocellulose and hybridized and washed at the indicated temperatures.

different randomly chosen $N$. gonorrhoeae and $N$. meningitidis strains (see Fig. 4). Table 2 illustrates that there is a broad fluctuation in sequence homology values (from 37 to $75 \%$ ). However, there is no absolute correlation between the percentage sequence homology and the specificity of the probes; probes from regions with low homology values are not always specific and vice versa. This might be due to differences in the mode or rate of evolution in different phyla and in the different regions of the rRNA molecules.

The results presented here indicate that there are small but consistent sequence differences in certain regions of the rRNA molecules of highly related taxa, which can be detected by a hybridization assay. This observation has some widespread implications for the use of rRNAderived probes in general. rRNA-derived DNA-probes cannot be used exclusively to identify large groups of organisms, but can be used to differentiate between organisms at the species or subspecies level. Provided that the probe sequence and the hybridization conditions are 


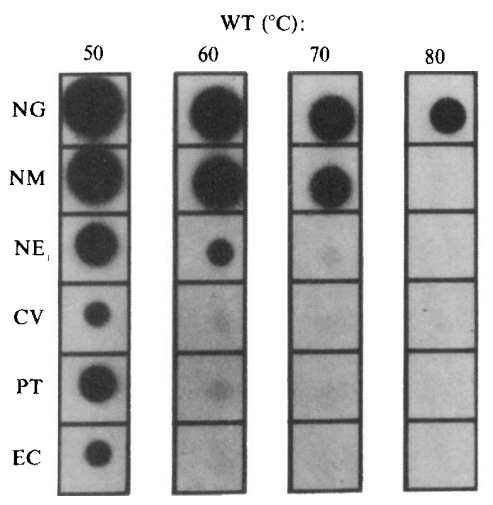

Fig. 8. Alteration of the detection range of a probe by changing the stringency of the wash conditions. Membranes, to which denatured DNA $(1 \mu \mathrm{g})$ from $N$. gonorrhoeae NCTC $8375^{\mathrm{T}}(\mathrm{NG}), N$. meningitidis NCTC $10025^{\prime}$ (NM), N. elongata ssp. elongata $\mathrm{NCTC}_{10860^{\mathrm{T}}}$ (NE), C. violaceum NCTC $9575^{\mathrm{NT}}$ (CV), P. testosteroni ATCC 17407 (PT) and E. coli $\mathrm{B}(\mathrm{EC})$ was fixed, were hybridized at $50^{\circ} \mathrm{C}$ with ${ }^{32} \mathrm{P}$ labelled probe 3 in the absence of formamide. Afterwards, the membranes were washed at 50, 60, 70 and $80^{\circ} \mathrm{C}$, respectively, in $3 \times \mathrm{SSC}$ and $25 \mathrm{~mm}-\mathrm{PB}$. The membranes were dried and autoradiographed overnight at $-70^{\circ} \mathrm{C}$ with an intensifying screen.

carefully chosen, highly specific identification can be accomplished in a simple dot-spot DNA:DNA hybridization format, making tedious Southern-blot analyses obsolete. In particular, some of the specific probes described in this report could find application in culture confirmation of $N$. gonorrhoeae and the diagnosis of $N$. gonorrhoeae in all types of clinical samples, since no interference is likely from other micro-organisms under appropriate hybridization conditions. Although highly specific probes are not an absolute prerequisite for this purpose, the probes described here can be used also for taxonomic or epidemiological investigations based on restriction fragment length polymorphism analysis (Grimont \& Grimont, 1986; Stull et al., 1988), or to identify and classify related but hitherto undescribed or unclassified micro-organisms.

We wish to thank Miss Martine Baudewijn for typing the manuscript.

\section{REFERENCES}

Brosius, J., Dull, T. J. \& Noller, H. F. (1980). Complete nucleotide sequence of a $23 \mathrm{~S}$ ribosomal RNA gene from Escherichia coli. Proceedings of the National Academy of Sciences of the United States of America 77, 201-204.

Brosius, J., Palmer, J. L., Kennedy, J. P. \& Noller, H. F. (1978). Complete nucleotide sequence of a $16 \mathrm{~S}$ ribosomal RNA gene from Escherichia coli. Proceedings of the National Academy of Sciences of the United States of America 75, 4801-4805.

Dams, E., Hendriks, L., Van de Peer, Y., Neefs, J.-M., SMits, G., VANDENBEMPT, I. \& DE WACHTER, R. (1988). Compilation of small ribosomal subunit RNA sequences. Nucleic Acids Research 16, r87r173.

De Ley, J. \& De Smedt, J. (1975). Improvements of the membrane filter method for DNA:rRNA hybridization. Antonie van Leeuwenhoek 41, 287307.

De Ley, J., Cattoir, H. \& Reynaerts, A. (1970). The quantitative measurements of DNA hybridizations from renaturation rates. European Journal of Biochemistry 12, 133-142.

Edelstein, P. H. (1986). Evaluation of the Gen-Probe DNA probe for the detection of legionellae in culture. Journal of Clinical Microbiology 23, 481-484.

Elwell, L. P. \& Falkow, S. (1977). Plasmids of the genus Neisseria. In The Gonococcus, pp. 138-154. Edited by R. B. Roberts. New York: John Wiley.

Festl, H., Ludwig, W. \& Schleifer, K. H. (1986). DNA hybridization probe for the Pseudomonas fluorescens group. Applied and Environmental Microbiology 52, 1190-1194.

Göbel, U. B., Geiser, A. \& Stanbridge, E. J. (1987). Oligonucleotide probes complementary to variable regions of ribosomal RNA discriminate between Mycoplasma species. Journal of General Microbiology 133, 1969-1974.

Grimont, F. \& Grimont, P. A. D. (1986). Ribosomal ribonucleic acid gene restriction patterns as potential taxonomic tools. Annales de l'Institut Pasteur 137B, 165-175. 
Guibourdenche, M., Popoff, M. Y. \& Riou, J. Y. (1986). Deoxyribonucleic acid relatedness among Neisseria gonorrhoeae, $N$. meningitidis, $N$. lactamica, $N$. cinerea and "Neisseria polysaccharea". Annales de l'Institut Pasteur 137B, 177-185.

HaUn, G. \& GöBeL, U. (1987). Oligonucleotide probes for genus-, species- and subspecies-specific identification of representatives of the genus Proteus. FEMS Microbiology Letters 43, 187-193.

HoKe, C. \& Vedros, N. A. (1982). Taxonomy of the neisseriae: deoxyribonucleic acid base composition, interspecific transformation, and deoxyribonucleic acid hybridization. International Journal of Systematic Bacteriology 32, 57-66.

Kahn, M., Kolter, R., Thomas, C., Figurski, D., Meyer, R., Remaut, E. \& Helinski, D. R. (1979). Plasmid cloning vehicles derived from plasmids ColE1, F, R6K, RK2. Methods in Enzymology 68, 268-280.

Kingsbury, D. T. (1967). Deoxyribonucleic acid homologies among species of the genus Neisseria. Journal of Bacteriology 94, 870-874.

Maniatis, T., Fritsch, E. F. \& Sambrook, J. (1982). Molecular Cloning: a Laboratory Manual. Cold Spring Harbor, NY: Cold Spring Harbor Laboratory.

MARMUR, J. A. (1961). A procedure for the isolation of deoxyribonucleic acid from micro-organisms. Journal of Molecular Biology 3, 208-218.

Noller, H. F. (1984). Structure of ribosomal RNA. Annual Review of Biochemistry 53, 119-162.

Palmer, L., Falkow, S. \& Klevan, L. (1986). 16S ribosomal RNA genes of Chlamydia trachomatis. In Clamydial Infections, pp. 89-92. Edited by D. Oriel,
G. Ridgway, J. Schachter, D. Taylor-Robinson \& M. Ward. Cambridge: Cambridge University Press.

Riou, J. Y., Guibourdenche, M. \& Popoff, M. Y. (1983). A new taxon in the genus Neisseria. Annales de l'Institut Pasteur 134B, 257-267.

Rossau, R., Van Landschoot, A., Mannheim, W. \& DE LEY, J. (1986). Inter- and intrageneric similarities of ribosomal ribonucleic acid cistrons of the Neisseriaceae. International Journal of Systematic Bacteriology 36, 323-332.

Rossau, R., Heyndrickx, L. \& Van Heuverswijn, H. (1988). Nucleotide sequence of a $16 \mathrm{~S}$ ribosomal RNA gene from Neisseria gonorrhoeae. Nucleic Acids Research 16, 6227.

Stull, T. L., LiPuma, J. J. \& Edlind, T. D. (1988). A broad spectrum probe for molecular epidemiology of bacteria: ribosomal RNA. Journal of Infectious Diseases 157, 280-286.

Tenover, F. C. (1988). Diagnostic deoxyribonucleic acid probes for infectious diseases. Clinical Microbiology Reviews 1, 82-101.

Wayne, L. G., Brenner, D. J., Colwell, R. R., Grimont, P. A. D., Kandler, O., Krichevsky, M. I., Moore, L. H., Moore, W. E. C., Murray, R. E. G., Stackebrandt, E., Starr, M. P. \& TRÜPER, H. G. (1987). Report of the ad hoc committee on reconciliation of approaches to bacterial systematics. International Journal of Systematic Bacteriology 37, 463-464.

Wilkinson, H. W., Sampson, J. S. \& Plikaytis, B. B. (1986). Evaluation of a commercial gene probe for identification of Legionella cultures. Journal of Clinical Microbiology 23, 217-220. 